\title{
非平衡構造（機能を伴う巨視的構造）
}

\author{
東北大学電気通信研究所 沢 田 康 次
}

\section{§1. 非平衡構造とは}

自然界は, 外界からの力が加わらない熱平衡の状態 でも，結晶のように美しい原子配列の構造を作るし， また強磁性体の磁区構造の様に巨視的な構造が出来る 原因も外力が働いているからではない。この様な平衡 状態での構造を平衡構造と呼ひ，これに反して，考え ている系に外力が加えられ流れが生じる事によって発 生する構造を非平衡と呼ぶ. 結晶が微視的な原子間力 に原因しているので構造が微視的である場合が多いが 外力は一般的に巨視的であるので, 非平衡構造は一般 に巨視的である. 自然現象の中で，どこか鋭く，何ん となく生き生きした形をとるものは非平衡棈造に関倸 がある場合が多い，入道雲やうろこ雲, 稲妻队河川の 分岐等……非平衡構造は現象面からは

1）時間的には定常で空間的に構造を持つ場合

2）空間的には一様で時間的には周期性を持つ場合

3）時間的または空間的に chaoticである場合

4）時間的に transientである場合

に分類される. いずれの場合も化学ポテンシャルの 高い熱源から低い熱源に向う流れがありエネルギー散 逸を伴う.このために非平衡構造は散逸構造 ${ }^{1)}$ とも呼 ばれている.2）と3) は化学反応系の現象として本誌 に藏本 ${ }^{12)}$ 氏の綕説があるので，この稿では1）と 4) を中心に述べてみる．また生物における散逸構造の例 については文献 1)を参照されたい。

この種の現象の熱力学的研究の先駆的役割は, プリ ゴジンとそのグループ1),3)が果して来たが, 私はここ で別の観点から非平衡楧造をとらえ, 様々な現象を統 一的に理解する試みを示す.

\section{§2. 単純なモデルによる非平衡構造の一般的 性質}

前節の分類で 1)の一番有名な例は，うろこ需の形 成に関係のあるべナール対流（写真1）である.下面 の金属が或る温度以上に熱せられると写真の様に規則 的な構造を作って液層が対流を定常的に続ける.これ

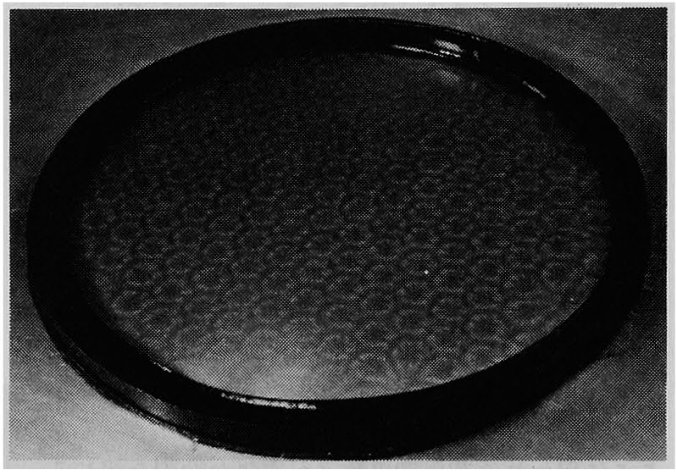

写真1 ベナール対流のセル櫣造

は下面に接触している液体の部分が充分に熱せられる と膨張して浮力が生じ、この力が粘性に打ち勝って上 昇し上面で冷され下降する.この場合, 興味ある点は, 空間的に一様に熱せられているのに，何故ある部分の 液体が上昇してそのまわりの液体が下降するのか. 形 と大きさはどの様に決るのであろうか。一般に非平衡 構造はどの様に決められるか，以上の点は，普通良く 引用される流体系 ${ }^{4)}$ や化学反応系 ${ }^{1)}$ のように連続系で は必ずしも理解が容易ではないので,ここでは簡単な

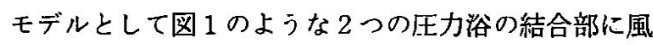
車を配列して見る.このモデルはつくりつけの部分が あって, 液体自身で構造を作る対流構造とは同一では

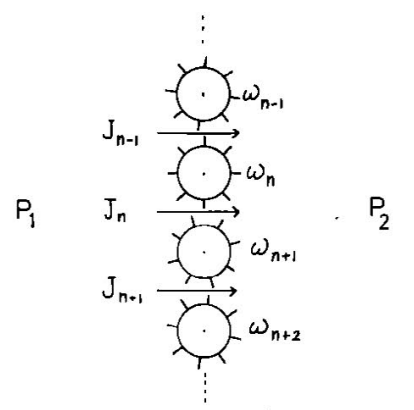

図12つの圧力浴の間に直か九た風車の列 
ないが，ロールを並行にならべた様な二次元的流線分 布を持っロール状対流と良く似ており，また非平衡構 造の一般的性質を持ち，得られた結果は定常非平衡構 造一般について云える. $n$ 番目の風車の回転速度 $\omega_{n}$, $n$ 番目と $n+1$ 番目の風車の間を通る流九 $J_{n}$ は次の式 に従う。

$$
\begin{aligned}
& I \dot{\omega}_{n}=a k\left(J_{n}-J_{n-1}\right)-\alpha \omega_{n} \\
& \dot{J}_{n}=\Delta P-K_{n}\left(\omega_{n}, \omega_{n+1}\right) J_{n}
\end{aligned}
$$

ここでKは流体の粘性保数， $\alpha$ は風車の抵抗， $\triangle P$ は 压力差， $K_{n}$ は $J_{n}$ に詨する見かけ上の抵抗で $\omega_{n-1}$ と $\omega_{n}$ に依存するから，一次迄展開して次の様に書く.

$$
K_{n}=K\left(1-\beta \omega_{n}+\beta \omega_{n+1}\right)
$$

$\omega_{n}$ は見かけの抵抗を增す样に働くから当然 $\beta$ は正と 考える。(3)式を用いると(2)は，

$$
\dot{j}_{n}=\Delta P-K\left(1-\beta \omega_{n}+\beta \omega_{n^{+1}}\right) J_{n}
$$

ここに現われる非線型釈数 $\beta$ が重要な役割を演じる. $こ の \omega と J$ の積の項は, 対流項と呼ばれるもので，も ともと流れているものを回転によって增大させる．写 真 1 の様なべナール対流問題では，この項に対応する

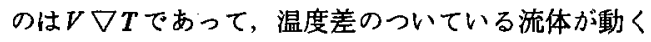
事によって熱の輸送が增大する. $J_{n}=J+j_{n}(J=$ $\triangle P / K)$ とおいて，(4)式で, $j_{n} \ll J$ の範囲の線型問 題にまず注目すると，(4)は

$$
\dot{j}_{n}=\beta \triangle P\left(\omega_{n}-\omega_{n+1}\right)-K j_{n}
$$

となる. $\omega_{n}=\omega^{0} \exp \left(Q(\theta)_{t}-\mathrm{in} \theta \cdot\right), j_{n}=j^{0} \exp$ $\left(\mathscr{R}(\theta)_{t}-\operatorname{in} \theta\right)$ の形を(1)式と(5)式に入れて， $\omega^{0}$ と $j^{0}$ の存在条件を求めると $\boldsymbol{Q}(\theta)$ に関して次の 2 次式を得 る.

$$
\begin{aligned}
I \Omega^{2}+(\alpha+I K) \Omega+\alpha K-4 a k \beta & \triangle P \sin ^{2}(\theta / 2) \\
& =0
\end{aligned}
$$

この 2 次方程式の解 $\Omega$ がある $\theta$ に対して正の值を取る 条件は，定数項が負，つまり

$$
\triangle P>\frac{\alpha K}{4 a \beta k \sin ^{2}(\theta / 2)}\left(\equiv \triangle P_{c}(\theta)\right)
$$

故に $\triangle P$ が右辺で与えられる $\triangle P_{c}$ 以上になると $\Omega$ が 正になって $\omega_{n}$ は時間と共に增大し，風車は回転速度 を增す. $\triangle P_{c}$ は $\theta=\pi$ の時, つまり風車が互い違いに 反対方向に回転するモードに対して一番小さい，これ
はロール状対流の流れ方と同じであり直感とも合う。 $\theta=0$ のモードつまり, 全ての風車が同方向に動くモ 一ドは $\triangle P_{e}$ が無限大となり存在しない. $\triangle P$ を図

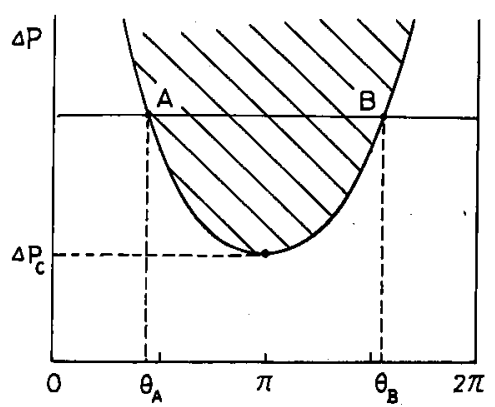

図2 不安定領域 ( 斜線部分)

に示した值にするとAから $\mathrm{B} の$ 閒の $\theta$ を持つ全ての乞 一ドが，以上の線型理論の範囲では可能となる. 2 図 の様に $\Omega>0$ で構造が生まれて来る領域は，対流や化 学反応等の線型理論では全て良く似た型で現われる.

次に $\omega_{n} や \jmath_{n}$ の大きさはどの様な值に決まるか.上 記の模型の籁囲内では時間と共に増大するが(1)式の抵 抗 $\alpha$ は，回転があまり速くなると $\alpha=\alpha_{0}+r \omega_{n}^{2}(r>0)$ の様に増大寸ると考えると，ある值に落着く，まず(4) から $\dot{J}_{n}=0$ とおき $\beta$ の 2 次迄展開寸る事により $J_{n}$ を 求める.

$$
\begin{aligned}
J_{n}= & \frac{\triangle P}{K}\left\{1+\beta\left(\omega_{n}-\omega_{n+1}\right)\right. \\
& \left.+\beta^{2}\left(\omega_{n}-\omega_{n+1}\right)^{2}\right\}
\end{aligned}
$$

これから平均流れは $n$ について平均すると 1 次の項は 例えば周期性境界条件より消えて

$$
\bar{J}(\theta)=\frac{\triangle P}{K}\left\{1+\frac{\beta^{2}}{N} \sum_{n=1}^{n}\left(\omega_{n+1}-\omega_{n}\right)^{2}\right\} \quad \text { (9) }
$$

これから， $\theta=\pi$ モードが $\bar{J}(\theta)$ の最大值

$$
\bar{J}(\pi)=\frac{\triangle P}{K}\left\{1+4 \beta^{2}|\omega|^{2}\right\}
$$

(10)

を与える事が判る、今後， $\theta=\pi$ のードのみに着目 してみよう. (8)から $J_{n}-J_{n-1}=-4 \beta \triangle P|\omega| / K$ たか ら(1)に入れて左辺をゼロにすると $|\omega|$ の大きさが次の 様に求まる。

$$
|\omega|^{2}=c^{2}\left(\triangle P / \triangle P_{c}-1\right)
$$


但し $c^{2}=\alpha_{0} / r$ である. この関係式も種々の非平衡構 造の振巾と外力との関係として共通のものである.こ の場合も, 風車の回転の構造を特徴ゔけるオーダーパ ラメーター $|\omega|$ は臨界圧力差からの才゙れの平方根に比 例する. 次に平均流を回転の無い時の流れ $\triangle P / K$ で割 ったナッセルト数 $N$ は(10)と(11)より

$$
N=1+4 \beta^{2} c^{2}\left(\triangle P / \triangle P_{c}-1\right)
$$

となり， $\triangle P$ が臨界值 $\Delta P_{c}$ を越えるとその差に比例 して增大する. $\triangle P$ を $\Delta T$ で直きかえると対流の場合 にあてはまる.

この様にモデル風車列によって示された様に，非平 衡棬造は，外力がある臨界値を越えた時に，今迄凍結 されていた自由度またはオーダーパラメーターが解放 されて，流れをより大きくした，逆に見れば，これは 流九を大きくする為に自由度を活用して構造を作った とも見る事が出来る．以上のモデルでも明らかな様に， 自由度は非線型性に強く関係している. 非平衡構造に 非線型性は是非とも必要である.

\section{§3. 準安定状態とその間の遷移}

前節で, 外力が一番小さい状態で励起されるのは, 風車列の場合は $\theta=\pi$ $\theta$ モードであって，そのモード が励起される事によって流れが増大する事を見た.と ころが圧力差が 2 図の $\mathrm{AB}$ 点を通る值に增加すると $\theta_{A}$ $<\theta<\theta_{B}$ のモードは全て $\Omega>0$ の領域に入っているか ら，少なくとも振巾が小さい間は増大しようとする. ところが，振巾がある程度増大すると，非線型項が無 視出来なくなって来て, 線型理論の $Q>0$ の領城のモ 一ドは全て安定な定常状態になり得るのかどうか. む し安定でもゆらぎに対する安定度が違うとすると,ど のモードが一番安定か等の問題については, 解析的手 法が無力である為に，あまり良く判っていない。

有限長で液層が $5 \mathrm{~mm}$ の対流セルは約 $10 \mathrm{~mm} の$ 波長を 持つロ一ル状対流構造が出来やすい）【）しかし, 波長 $8 \sim 12 \mathrm{~mm}$ のロールを作為的に作ると, 容器の形状に も多少はよるが比較的長時間安定に存在しつつける. 数時間経っと,この内の何らかの構造が消えるか新し く発生するかして一番安定と思われる $\lambda=10 \mathrm{~mm}$ 近辺 の構造に戻る.この様に臨界值よりもずっ上大きい外 カが, かかっている時に, どのモードが一番安定であ るか. 対流の場合は, ある数值計算 ${ }^{5}$ によると、“ゆ らぎに対して一番安定なモードは，一番多くの熱流を 運ぶモードにほぼ等しい”事が判っている.そうであ れば强制的に別のモードを作って放置すると流れを增や
す方向に構造が変化した事になる．私は，この事は一 般的な事たと考えている. “一般に非線型非平衡状態 では多くの準安定状態が存在するが，その中でゆらぎ に対して一番安定な状態は，一定外力に対する流れを 最大にする”この理由は後から述べる事にしてもう一 つ例を示そう.

ブラッセレーターと呼ばれる次の反応系を考えよう.

$$
\begin{aligned}
& \partial X / \partial_{t}=A-(B+1) X+X^{2} Y+D_{\mathrm{X}} \partial^{2} X / \partial R^{2} \\
& \partial Y / \partial_{t}=B \mathrm{X}-X^{2} Y+D_{\mathrm{Y}} \partial^{2} Y / \partial R^{2}
\end{aligned}
$$

この有名な反応系については文献 ${ }^{3)}$ に詳しいからここ では説明しないが，本質的に風車の列や対流の場合と 同じで，パラメーターA， Bや拡散定数がある関係を 満せば，Xと Yが空間的に構造を作るようになる（写 真 2 ).この場合も波長を決める原理は何かと云う問

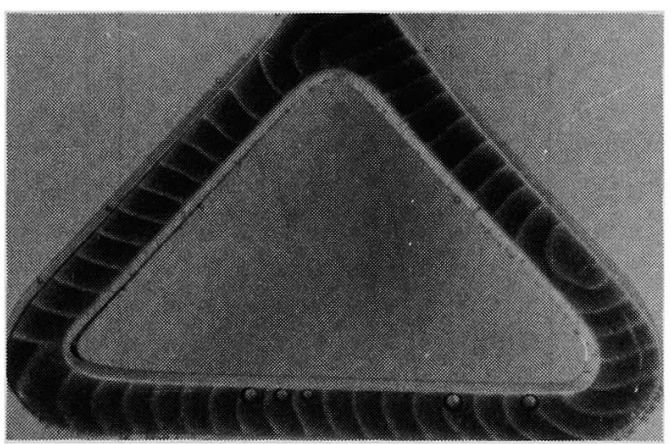

写真 2 化学反応による周期構造.

$1.5 \mathrm{M} \mathrm{H}_{2} \mathrm{SO}_{4}, 4 \mathrm{mM} \mathrm{Ce}\left(\mathrm{SO}_{4}\right)_{3}$

$0.25 \mathrm{M} \mathrm{KB}_{\mathrm{r}} \mathrm{O}_{3}$, 1.2 M Malonic Acid

題は生物の構造との関係においても大切な問題である.

図 3 に示したようなパラメーターを仮定した場合は， 一次元模型においては $\lambda=0.05$ から $\lambda=0.24$ の範囲 で準安定状態を作る. $\lambda=0.04$ の波を初期条件とす ると，振巾が小さい閒は成長するが，振巾がある值に 達すると非線型項がきいて来て $\lambda=0.08$ のードに 移行する. 図 3 はそのモードが移っている途中の様子 を示した. 図 4 には種々の準安定モードが定常に達し た時のエントロピー生成量を示してある。エントロピ 一生成量は，一般に定常状態においては，外力とそれ

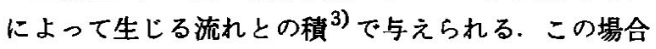
は外力は, 初期物澌と生成物質の化学ポテンシャルの 差であり，流れは化学反応速度である?3) もしも力を 一定に保てば，エントロピー生成は定常反応に比例す 


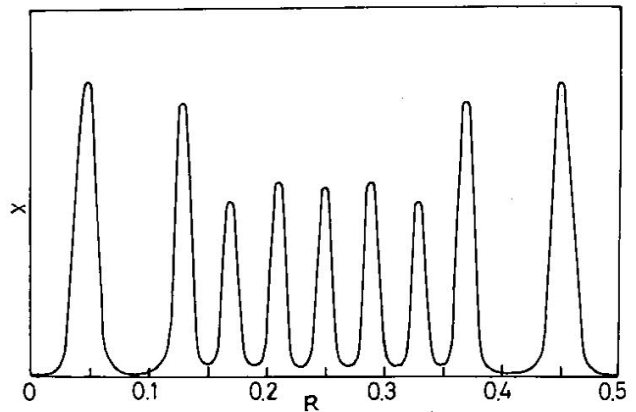

図3 化学反応(ブラッセレーター)による空間椿造の 数值計算. $\mathrm{D}_{\mathrm{x}}=1.052 \times 10^{-3} \quad \mathrm{D}_{\mathrm{y}}=0.0256$ $\mathrm{D}_{\mathrm{B}}=10.0 \quad \mathrm{l}$ (波長) $=0.5 \quad \mathrm{~A}=10.0 \quad \mathrm{~B}_{\mathrm{o}}=70$ $\mathrm{Y}_{\mathrm{o}}=7.0$ 横軸 $\mathrm{R}$ 空間座標, 縦軸 $\mathrm{X}$ は X濃度.

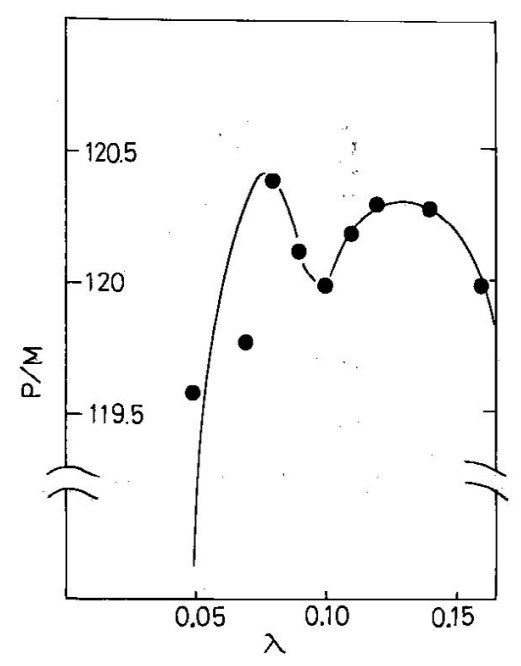

図4图3に示した化学構造の単位質量当り のエントロピー生成.

る. 図 4 では $\lambda=0.08$ のードがこれを最大にする さて計算機実験において $\lambda=0.08$ のードに $\lambda=0.16$ の雑音をパルス的に加えた時と，逆に $\lambda=0.08$ の 一ドに $\lambda=0.08$ の雑音を加えた時とを比較すると $=0.08$ モードがより安定である事が判る. したがっ てこの場合も，エントロピーの生成量が最大(定常状 態では流れ最大と同じ）になるモードがより安定であ るらしい，計算は有限の一次元セルに対して行なった が，準安定状態の安定性は，セルの長さや境界条件に も依存する。

\section{§4. 非定常非平衡構造}

ここでは, 写真 3 と写真 4 の様に, 時閒と共に成長 して行くが，その成長の仕方に構造がみられる場合を 考えて見よう. 写真 3 は， $0.5 \mathrm{~mm} の$ 毛紐管に閉じこめ

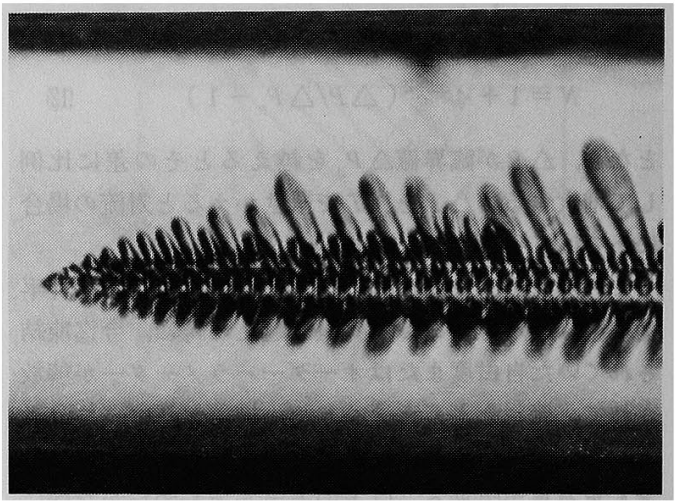

写真 $3 \mathrm{NH}_{4} \mathrm{~B}_{\mathrm{r}}$ の過飽和溶液から成長する樹枝状結晶

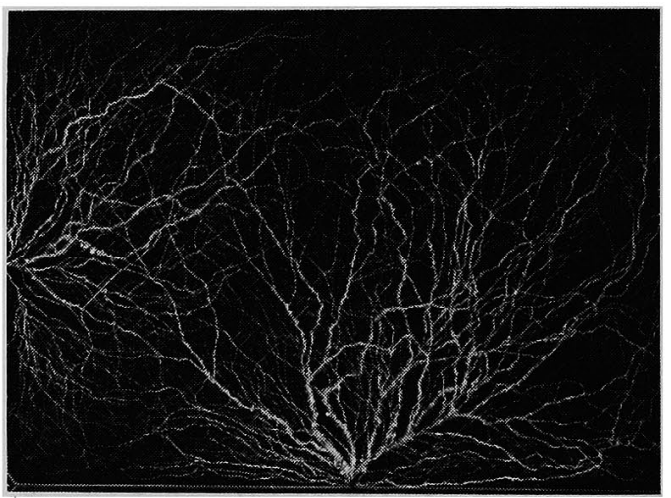

写真 4 絶縁破壊パターン

られた過飽和の $\mathrm{NH}_{4} \mathrm{Br}$ 溶液から成長している樹枝状 結晶である. 樹枝状結晶の形状はその成長過程におい てのみ見られるものであって，溶液と平衡状態として 共存しているのではない.この意味で非平衡楧造なの である. 成長が止まると除々に枝葉がとれて幹むきれ ぎれになって小さな球状になる.

さて，この美しい周期構造はどのようにして出来る のか，特にこの波長は何によって決まるか．最近の定 量的実験によると, 先端の成長速度は過飽和度の平方 根に比例し，先端の曲率半径と側枝の間隔は過飽和度 に逆比例する6) この場合も横枝がほんの少ししか出 ていない場合を考えた線型計算によると，波長が無限 大からある䠦界值 $\lambda_{c}$ の間全てのモードが可能である. 


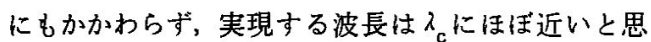
われる.6),7) この事は, 過飽和度が大きくて非線形勃 果が無視出来ない成長過程にあっては 小さくして表面橨を增大し，単位時閒の結晶化量を增 大しようとしている様に見える.

写真 4 は，アクリル板に高エネルギー電子を一様に 打ち込んでから或る点を接地した際に形成された絶縁 破壊のパターンである? 接地された瞬間は，その点 の囲りの電子が一番強い力を感して絶縁破壊を起こす。 するとその通り道はプラズマ状態となり, 接地電位に 近くなる.したがってこの形成された道の囲りの電子 が，その道に向けて絶縁破壊を起こす。この様なプロ 七スが確率的に起きて枝莱を形うくくって行くものと考 えられる.ただし先端には電界が集中するので，先端 がどんどん伸びて行く率が幹から枝が出る率よりも一 般に大きいと考えられるが，この比がパターンを決め ろ.

絶縁破壊のパターンを計算機シミレーションした例 が写真 5 である.パラメーターは先端の放電確率と先 端以外の部分からの放電確率の比 $r$ である. $r$ が小さい 場合は先端の優先性が無視出来て絶縁破壊領域は円状 に拉がるが，rがある值をこえると，先端の放電が続 いて起こり，放電領域が線状になって伸びる，写真 5 (a) は $r=1$, (b) は $r=100$ で両方共放電が 3000 回

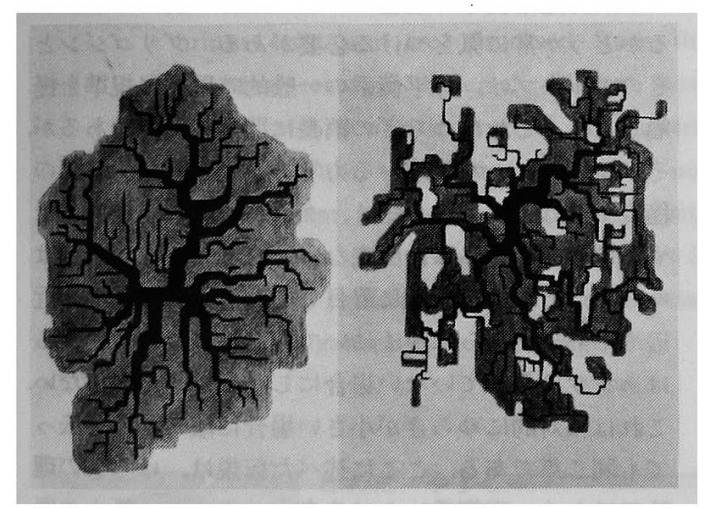

(a)

(b)

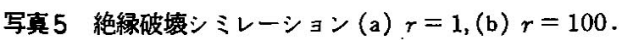

起きた時の様子である. 灰色の領域は既に電荷が逃げ た領域であり苯脈状構造はその通り路で太さは通った 電荷量に関係している.

図 5 は放電額域の面積 $S$ と周長 $L$ が時間と共に増加 する様子を示したものである.ごく初期を除くと $S$ も $L$ 女時間 $T$ のべき乗に比例している. このべきの比
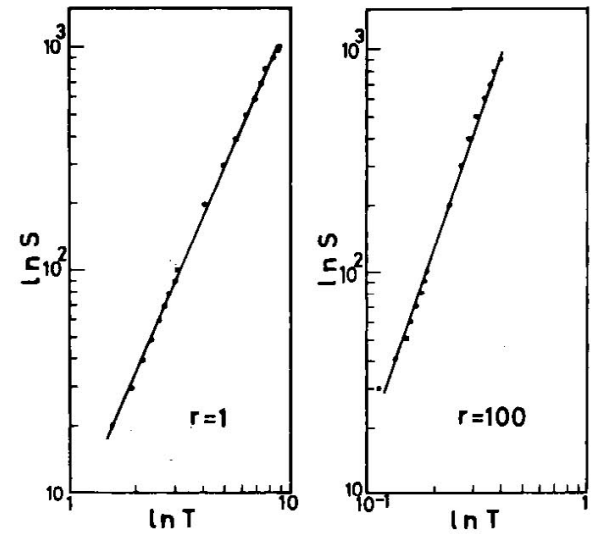

图 5(a) 放電領域の面積 $S$ の時間变化
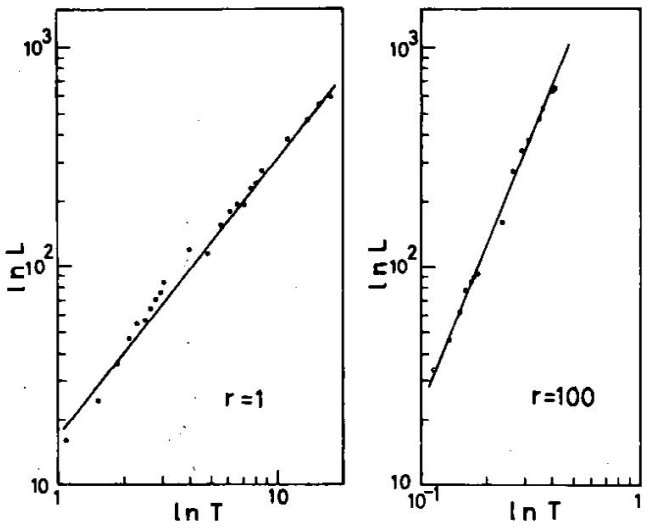

(b) 放電頖域の周長 $L$ の時間変化

$\left.D \equiv\left(\frac{d \ln S}{d \ln T}\right)\right|_{d} ^{d}\left(\frac{\ln L}{\ln T}\right\}$ は 1 と 2 間にあり一種の次 元を与える. 図 6 は $D$ を $r$ 関数としてプロットした

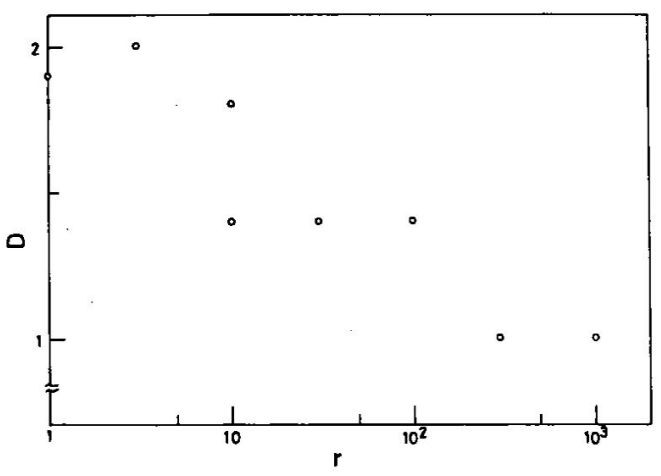

图6 図形の次元 $D\llcorner r$ の関倸 
ものである. $r \sim 10$ の近辺を境にして $D=2 か ら D$ $=1.4$ に移る. $D=2$ の時は写真 5 からも判るように 放電領域かなめなかに增大するが $D=1.4$ になると境 界の出入がはげしくなり，内部に未放電領域が置きざ りにされる.

この様に非定常現象で一見ランダムに見える構造に も，時間と無関倸なパラメーターDが存在して図形の 特徴を決めている.つぎに図形の変化の意味を考えて

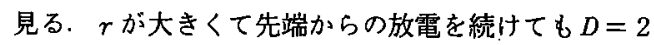
のパターンを作る事は不可能ではない，ただ確率は非 常に小さい，少しの図形のゆらぎで $D$ は 2 からはずれ

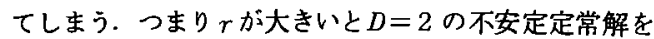
持っ. 一方 $r か ゙$ 小さいと $D=2$ 以外には，安定不安定 にかかわらず定常解は無い：これは対流に対する熱力 学的解积と同様に，次の様な解釈が可能である事を示 唆している.

“絶縁破壊パターンは，可能な限り $D$ を下げて，同 し放電量 $S$ に対する周長 $L$ を大きくし， $S$ の堌化率 $d S / d t$ を增そうとする” 何故ならば $\frac{d S}{d t}$ は $L$ と共に增 大し $L=S^{1 / D}$ だからである.

河川の枝分れ模様や毛細血管の分布等も，一見規則 性が無い様に見えるがどこか似ている事は，いずれる 何か一様に分布したものをある点に輸送する系路であ り, 当然その為に何らかの共通性を持つのであろう. この様なパターンに対する研究は最近始まったばかり でありまだ結論的な事は云えないが，輸送効率，つま り出来るだけ速く与えられた量を目的地に運ふように 采路が形成されている事は充分考えられる。

\section{§5. 非平衡構造の熱力学}

前節までで, 種々の非平衡構造が，簡単な共通した 性質，つまり構造の機能とも云うべき量を增大にして いる場合が多い事を見て来た．定常構造の場合は，粒 子源も含む一般的熱源が 2 ケ以上あり一方の熱源から 他の熱源に運ぶ量を最大にし，非定常構造の場合は， 考えている系が1つの熱源にうめこまれていて，その 熱源とのエネルギーや粒子のやり取りを出来るだけ速 くして，熱源を含む全系の平衡を達成しようとするか の棣に見える. 平衡状態はエントロピー最大の状態で あるから，出来るだけ速く平衡を達成する様な粠造を とると云う事は，各熱浴は可逆的変化を考えているか ら, 注目している采がエントロピー増加率最大の構造 を選ぶと云う事になる. かくして次の仮説が生れる.

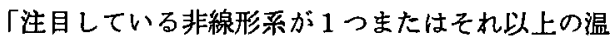
度や化学ポテンシャルの異る熱浴を結びつけている時,
この系は自分の内部自由度を駆使して, 全系のエント ロピーを出来るだけ速く増加させるような構造をとる」

もちろんエントロピーは時間と共に增加しなければ ならない事は熱力学第二法則の要請である.

$$
\triangle S=S(t+\Delta t)-S(t) \geq^{0}
$$

このことから直ちに熱伝導度は正になる.もし仮に系が 2つの定常状態をとることができるとする．構造の組み 替えに要する時間よりはるかに長い時間 $\triangle t$ の後を考

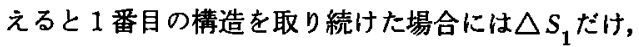
また 2 番目の構造を取った時には $\triangle S_{2}$ だけエントロピ 一が増大すると考え， $\triangle S_{2}>\triangle S_{1}$ であるとする。(15) 式が成立する為に熱流が温度の高い方から温度の低い 方に流れる確率が圧倒的に多いのと同じ理由で，この 場合は熱であ九粒子であれの流れが，2 番目の構造を 通って起きる確率が，1番目の構造に比べて圧倒的に 多いのである. これが上記の仮説の物理的背景である.

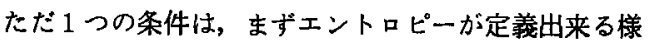
な条件であり，更に考えるタイムスケールが構造を組 み替えるのに要する時間よりも長い事である。たとえ ば 1 番目の構造が準安定状態であれば，小さなゆらぎ が来ても 2 番目の構造には移らないから充分大きな中 らぎが系に及ぶ迄の時間より大きいタイムスケールで の話である. したがって，定常構造の場合は問題はな いが，非定常現象の場合は，この条件が満たされてい るかどうか常に気をつける必要がある。プリゴジンと そのグループは，非平衡系の一般的時間発展規準を提 唱しだ。。 これはいらぎの消長に関する理論であるが, その時間スケールは用いる力学方程式の特徽的時間の 程度またはそれよりも短く，グローバルな安定性に対 する規準を与える事は出来ない。プリゴシンの理論は ゆらぎの 2 次の量のみに着目している為に，熱平衡近 辺や，熱平衡からは遠くにいても基準になる状態から はあまりはなれていない場合にしか使う事が出来ない， これは相対的にゆらぎが小さい場合に限られると云っ ても同じ事である.ここに述べた仮説は，中らぎの理 論ではなく，平衡系における自由エネルギ一最小の原 理と全く同様に，エントロビー生成と云うマクロ量の 大小によって安定性を判別しょうと云うのである. 強 いてプリゴジン理論と比較を行なえば，ゆらぎの 1 次 の量を扱っているとむ云える. 1 次の量と 2 次の量は 時間スケールが全く違うし，観測するタイムスケール が異なると現象は異なって見えるのである．生物個体， 生物の一部队生物集団を非平衡系とみる試みも多い! 生物の発生, 進化等の重要な問題がどのような一般的 
法則に従っているのか、ここで述べた非平衡構造の持 つ一般的性質とどの様に関係があるのか興味はつきな W.

研究室の太田正之輔, 中島凄治, 鈴木誠, 本庄春雄, 清水裕等の諸名との議論を通して得る所が多かった. また数値計算は全てこの諸君がやった.ここに謝辞を のペる.

\section{文献}

1)「散逸構造」, ニュリス, プリゴジース著, 小香陽之助, 相沢洋二訳，(岩波書店 1980 )。

2) 蔵本由起; 生物物理 $19,11(1979)$.
3）「等造・安定性・ゆらぎ」グランズドルフ,プリゴジン 著, 松本元, 竹山脇三著（みす寸゚書房 1977 )。

4) S. Chandraseckar; Hydrodynamic and Hydromagnetic Stability, (Clarendon Press 1961).

5) P. H. Roberts; Nonequilibrium Thermodynamics, Variational Technique and Stability ed. R. J. Donelly, R. Herman and I. Prigogine, University of Chicago Press 1964).

6) H. Honjo, Y. Sawada (to be published)

7) S. Langer; Rev. Mod. Phys. 52, 1 (1980).

8）古川電工の小田英輔氏の好意に上る.

\begin{abstract}
Nonequilibrium Structures (Macroscopic Structures with Functions)

Yasuji SAWADA

Research Institute of Electrical Communication, Tohoku University
\end{abstract}

A series of interacting windmills placed between the two reservoirs of different pressures is presented as a model to explain general features of nonequilibrium structures. General properties of metastable states which arise when a generalized force greatly exceeds a critical value for establishment of a nonequilibrium structure are discussed from the examples of Benard convection and chemical reaction systems. Pattern formation in nonequilibrium systems is discussed with dendritic crystals and electric breakdown as examples of nonsteady nonequilibrium structures. Many of nonequilibrium structures, steady or nonsteady, seem to be explainable by a principle that the rate of increase of total entropy in a system including reservoirs is always maximum. The condition under which this principle is valid are discussed, and the principle is compared with Prigogine's general evolution criterion.

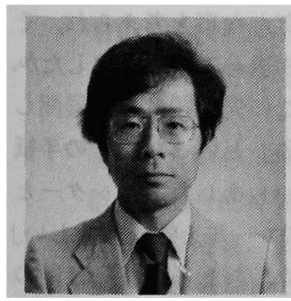

さわだ

やすじ

1960年 東京大学工学部卒. ペンシルヴェニア大学物理 ph.D. ('66)，大阪 大学理学部物理講師 ( '68) を経, 1973 年 東北大学電気通信研究所教授. 生 物を含む非線型非平衡系の熱力学を研究.『知的には核戦争の可能性に深い危惧 を持ちながら，それが日常感覚となって来ないところに自分の知性の限界を感じ ている』 $\ell(0222) 27-6200$ 内線 2356 . 